\title{
FENOMENA PENGELOLAAN ATRAKSI WISATA SWAFOTO DAN \\ IMPLIKASINYA BAGI MASYARAKAT DI DESA WANAGIRI KECAMATAN SUKASADA KABUPATEN BULELENG
}

\author{
I Gede Ngurah Wirayuda Arsana \\ Fakultas Pariwisata Universitas Udayana \\ Email: yudi.wirayuda@gmail.com \\ I Nyoman Sunarta \\ Fakultas Pariwisata Universitas Udayana \\ Email: carins54@yahoo.com \\ I Nyoman Sukma Arida \\ Fakultas Pariwisata Universitas Udayana \\ Email: sukmaarida@unud.ac.id
}

\begin{abstract}
The increase in number of tourists dominated by millenials that always wants to get attention on Instagram (instagrammable) or other social media, such as facebook, whatsapp, line, and twitter giving opportunities to community of Wanagiri Village for developing selfie tourism. Along with their creativity, community of Wanagiri Village carried out selfie tourism around Nature Tourism Park of Lake Buyan and Tamblingan, which increased disharmony between local people (in this case represented by desa adat) with local government. This research was conducted based on qualitative research with descriptive model, which the purposes are: 1) Knowing the development of selfie tourism in Wanagiri Village; 2) Examining the implementation of policies for selfie tourism in Wanagiri Village; 3) Knowing the implications of selfie tourism for local people in Wanagiri Village. The results showed three main things. First, selfie tourism in Wanagiri Village creates relation pattern between the desa adat Wanagiri, Bali Natural Resources Conservation Center, Buleleng Regency Tourism Office, and the investors. The relation pattern forms synergy that occurs between all of them through the beliefs and all parties to regulation, as happened in Balinese concept "Sagilik Saguluk Salunglung Sabayantaka". Second, there are job diversification. Last, public awareness of nature conservation can be maintained.
\end{abstract}

Keywords: Selfie tourism, Wanagiri Village, Development policy 


\section{Pendahuluan}

Desa Wanagiri, Kecamatan Sukasada, Kabupaten Buleleng kini bergeliat membangun berbagai potensi alam yang dimiliki desanya. Terletak di atas ketinggian yang merupakan kaldera pegunungan purba. Memiliki bentang alam berupa pemandangan hutan yang masih asri, udara sejuk, terkadang turunnya kabut putih menyelimuti panorama Danau Buyan dan Danau Tamblingan di bawahnya menjadi perpaduan eksotis sekaligus unik di berbagai hasil foto wisatawan. Beberapa penginapan kebanyakan milik investor dari luar Desa Wanagiri maupun pejabat Pemerintah Provinsi Bali saat ini terbangun menghadap lembah dengan pemandangan kebun sayur dan bunga milik petani penggarap sebagai daya tariknya. Keseluruhan fakta tersebut belum mampu mengangkat nama Desa Wanagiri menjadi terkenal seperti saat ini. Namun sejak maraknya fenomena swafoto (selfie) yang dilakukan wisatawan dengan mengunggah foto-fotonya melalui media sosial, menarik minat wisatawan untuk datang mencari tempattempat yang unik untuk berfoto melalui penciptaan sisi yang menarik untuk tampil di Instagram (instagrammable) sebagai pemenuhan keinginan wisatawan(Listiono, 2017)

Hal ini senada dengan penelitian yang menyatakan bahwa penggunaan media sosial dapat meningkatkan minat berwisata (Hamzah, 2013). Selain itu, media sosial juga terbukti dapat menghadirkan sebuah destinasi wisata dan menciptakan atribut baru (Pitanatri dan Putra, 2016). Dukungan teknologi informasi dan komunikasi khususnya penggunaan smartphone, mempermudah bagi wisatawan mengakses informasi mengenai destinasi wisata baru yang akan dituju dengan motivasi mendapatkan pengalaman baru tentang budaya dan alam setempat serta keinginan untuk belajar budaya lokal (Sunarta dkk., 2017). Lebih lanjut, masyarakat Desa Wanagiri memanfaatkan fenomena swafoto menjadi sebuah atraksi wisata dengan memanfaatkan sempadan danau yang berada di sepanjang jalan Wanagiri-Munduk, dimana merupakan kawasan konservasi Taman Wisata Alam (TWA) Danau Buyan 
dan Tamblingan. Berdasarkan kesepakatan bersama antara pihak BKSDA Provinsi Bali dan Desa Adat Wanagiri disepakati hanya empat titik lokasi yang terletak di masing-masing banjar adat di wilayah Desa Wanagiri.

Wisatawan yang memposting foto dirinya di media sosial menjadikan wisata swafoto di Desa Wanagiri semakin popular. Keberhasilan salah satu kelompok dalam mengelola atraksi swafoto, memunculkan keinginan warga masyarakat lain terus membangun anjungan di pinggir tebing Danau Buyan dan Danau Tamblingan hingga mencapai enam titik lokasi. Ketidak berdayaan aparat pemerintah desa dinas dan desa adat Wanagiri menahan laju keinginan masyarakatnya untuk membangun anjungan swafoto sesuai kreativitas pengelola terus berlangsung hingga ke hutanhutan desa. Berbagai model anjungan berbentuk sarang burung,ayunan bahkan flying fox mulai dikembangkan sebagai alternatif wisatawan untuk berswafoto. Menurut sejumlah wisatawan, berswafoto sambil bermain ayunan di atas ketinggian menjadi sangat populer ketika diposting di media sosial, dimana hal tersebut akhirnya ditiru wisatawan lain untuk datang dan melakukannya (Pearce, 2015).

Seiring meningkatnya jumlah kunjungan wisatawan hingga mencapai 200 orang per hari, jumlah titik-titik lokasi wahana atraksi bertambah hingga mencapai enam lokasi. Permasalahan kemudian muncul ketika secara densitas (jumlah dan jarak dari dan antar setiap anjungan) kini kurang lebih hanya 10 meter terlihat di Banjar Adat Yeh Ketipat. Kondisi saling berdekatan antara swafoto Pucak Selfie, Cemara Kembar, Kreteg Selfie, Selfie Pak Oles berakibat susahnya kendaraan parkir bagi pengunjung atau yang hendak melintas. Belum lagi adanya atraksi reptile yang berebut menggunakan lahan bagi atraksi swafoto. Tidak jarang terjadi kesalahpahaman diantara pengelola atraksi swafoto dan pemilik restauran yang ada disekitar atraksi swafoto karena lahan parkirnya digunakan oleh wisatawan yang akan berswafoto. Melihat berbagai kejadian tersebut, pihak Balai Konservasi Sumber Daya Alam (BKSDA) Bali, sempat memberikan teguran kepada masyarakat melalui Perbekel Desa Wanagiri dan Kelihan Adat Desa Wanagiri untuk menghentikan pembangunan wahana-wahana swafoto (selfie). Usaha penutupan wahana swafoto 
mendapat reaksi dari masyarakat. Secara ekonomi masyarakat merasa dirugikan karena biaya pembangunan wahana swafoto mencapai 50-60 juta per titik lokasi di tambah biaya untuk menggaji anggota belum dapat dinikmati. Berdasarkan surat dari BKSDA Provinsi Bali nomor S.365/BKSDA.BI-1/WA/2018 serta dimediasi oleh Kepala Dinas Pariwisata Kabupaten Buleleng, kembali menegaskan pemberian rekomendasi kepada empat banjar adat yang terdapat di Desa Wanagiri. Kebijakan tersebut diberikan sebagai upaya persuasive pihak BKSDA Bali untuk mengindarkan konflik horizontal yang terjadi di masyarakat.

Berdasarkan kebijakan yang telah ada saat ini, Desa Wanagiri dengan seluruh potensi dan letak geografis serta aksesibilitas tinggi yang dimilikinya sesungguhnya merupakan bagian dari Kawasan Daerah Tujuan Wisata Khusus (KDTWK) Bedugul - Pancasari dan Sekitarnya. Sifat khusus yang dimiliki sebuah destinasi, karena kawasan tersebut memiliki peran penting terhadap konservasi sumber daya alam, sebagai daerah resapan, perlindungan budaya dan religi bagi masyarakat lintas sektoral. Dengan berbagai pertimbangan empiris tersebut, pengembangan destinasi wisata baru berupa atraksi swafoto yang terdapat di Desa Wanagiri menjadi penting untuk dikaji lebih lanjut. Perebutan ruang kelola dalam pemanfaatan kawasan konservasi sebagai atraksi wisata swafoto di antara Pemerintah Daerah Kabupaten Buleleng, masyarakat Desa Wanagiri dan Balai Konservasi Sumber Daya Alam (BKSDA) Bali menjadi fokus penelitian ini.

\section{Landasan Teori dan Konsep}

\section{Swafoto}

Swafoto (selfie) menurut kamus Oxford adalah sebuah foto diri yang diambil oleh dirinya sendiri, biasanya (typically) diambil dengan menggunakan smartphone atau webcam dan diunggah melalui media sosial (Pearce dan Moscardo, 2015). Pengertian tersebut tidak jauh berbeda dengan apa yang ditemukan dalam Kamus Besar Bahasa Indonesia tahun 2016 yang mendefinisikan swafoto (selfie) sebagai 
potret diri yang diambil sendiri dengan menggunakan kamera ponsel atau kamera digital, biasanya untuk diunggah ke media sosial. Kusrini mendefinisikan selfie sebagai pengambilan foto dilakukan oleh diri sendiri. Artinya, terdapat pertimbangan kapan harus menekan shutter atau tombol handphone sehingga paham betul posisi wajah maupun badan yang akan difoto. Pemikiran itu kemudian mengarahkan pandangan mata kepada layar penampil gambar di kamera atau pada hal lain di luar jendela bidik sehingga arah mata subjek foto biasanya tidak terfokus pada sebuah arah tertentu (Kusrini, 2013).

Ketiga definisi ini kemudian berkembang, karena foto tersebut nantinya akan diunggah ke dalam media sosial. Dengan mengambil inspirasi dari Urry dan Larsen, maka hal tersebut dapat dikatakan sebagai selfie gaze, yaitu gambar diri yang diambil dengan pertimbangan audience yang melihat gambar tersebut (Urry dan Larsen, 2011). Dengan kata lain, sebuah gambar selfie akan mencari elemen landskap dan presentasi diri yang terbaik, agar foto tersebut disetujui (approved) oleh audience. Motivasi seseorang melakukan selfie adalah menjalin (engage) komunikasi dengan orang yang dicintai (significant others), membangun dan mengelola relasi sosial, membagikan konten kepada grup (share in communal), dan membangun identitas (Pearce dan Moscardo, 2015).

Terdapat tiga nilai yang menggerakkan sebuah selfie gaze. Pertama, nilai pengawasan berarti terdapat batasan antara konten "publik" dan "privat", sehingga perlu memperhatikan implikasi personal, profesional dan sosial ketika foto diunggah. Kedua, nilai mikro-selebritas berarti wisatawan dapat membangun kepercayaan diri dalam konteks sosial (social esteem) dengan cara membagikan konten yang layak (appropriate), melalui perhatian audiens (attention economy) dan ekspos publik (exposure). Terakhir, nilai keseluruhan suara publik (omnivorous voice) berarti motivasi ekstrinsik (berasal dari luar diri) yang bertujuan untuk menarik perhatian publik (mass appeal) dibandingkan sebuah kepentingan pribadi. Ketiga nilai ini memberikan batasan normatif bagi orang - orang yang mengambil dan mengunggah foto selfie tersebut, sesuai dengan konsep panopticon (Foucault, 1975). 


\section{Konsep Kebijakan}

Kebijakan dalam kamus Merriam-Webster diartikan sebagi aturan yang secara resmi diakui sebagai pedoman dalam melaksanakan aktivitas. Edgel dan Swanson menyatakan bahwa kebijakan merupakan arah tindakan atau cara bertindak yang dipilih didasarkan alternatif yang tersedia dengan mempertimbangkan kondisi faktual sebagai penentu pengambilan keputusan di masa kini dan masa depan (Antariksa, 2016). Dalam bidang kepariwisataan, berbagai macam aturan, strategi, dan sasaran pembangunan atau promosi pariwisata menjadi pedoman bagi pengambilan keputusan dalam jangka pendek maupun jangka panjang. Kebijakan yang dikeluarkan harus memberikan jaminan dengan tujuan utamanya untuk membuat masyarakat yang tinggal di destinasi pariwisata bersangkutan mendapat keuntungan optimal dari kontribusi kepariwisataan dibidang sosial dan ekonomi dalam bentuk kemajuan dan kualitas hidup.

Kebijakan juga merupakan keseluruhan tindakan dari pemerintah yang digambarkan sebagai pernyataan umum dengan maksud memberi petunjuk tentang tindakan pelaksana dan lainnya yang melaksanakan tujuan pemerintah (Pitana, 2009). Berdasarkan definisi tersebut, Edgell dan Swanson menyimpulkan bahwa kebijakan di bidang kepariwisataan adalah setiap tindakan pemerintah baik di bidang legislatif, administratif mapun yudisial yang berpengaruh terhadap kepariwisataan (Antariksa, 2016). McDougel menyatakan kebijakan seharusnya dapat berfungsi sebagai agen perubahan sosial yang terarah dan sistematis sehingga dapat mengantarkan pada derajat kehidupan komunitas masyarakat yang lebih baik (Putra, 2016).

Penggunaan istilah kebijakan (policy) memiliki arti yang berbeda dengan kebijaksanaan (wisdom). Penggunaan istilah kebijakan (policy) dan kebijaksanaan (wisdom) dalam hukum administrasi negara atapun dalam pemahaman masyarakat sering diartikan sama. Kebijaksanaan dapat dipandang sebagai hasil pemikiran yang mendalam untuk menjadi dasar bagi perumusan kebijakan. Kebijakan lebih 
menekankan kepada aturan yang di tetapkan pemerintah pusat, sedangkan kebijaksanaan lebih kepada bagaimana upaya pelaksanaan oleh lembaga-lembaga di daerah. Terkait dengan kebijakan dan kebijaksanaan, kebijakan dapat disebut sebagai sebuah konsep, ancar-ancar, rencana yang berhubungan dengan politik, sedangkan kebijaksanaan disebut sebagai diskresi yang merupakan kebebasan bertindak untuk merealisir kebijakan.

Dari berbagai definisi yang dijelaskan sebelumnya, penelitian ini akan mengkaji lebih mendalam mengenai kebijaksanaan yang dikeluarkan oleh pihak BKSDA Provinsi Bali, Perbekel dan Bendesa Adat Wanagiri, baik berupa ketetapan maupun kesepakatan otentik maupun lisan, serta tindakan, terkait keberadaan atraksi wisata swafoto di Desa Wanagiri serta dampak secara khusus bagi para pengelola dan masyarakat pada umumnya.

\section{Pengelolaan Atraksi Wisata}

Pengelolaan menurut Leiper, merupakan penciptaan seperangkat aturan oleh seseorang atau sekelompok orang, yang berfungsi sebagai alat untuk melakukan perencanaan, mengarahkan, koordinasi, serta pengawasan (Pitana, 2009). Lebih lanjut, Follet menekankan bahwa koordinasi merupakan fungsi utama dan terpenting yang harus dipisahkan dan memerlukan pembahasan tersendiri. Fungsi koordinasi merujuk kepada fungsi seorang manajer untuk menerjemahkan sebuah informasi, seperti perencanaan dan pengawasan,dan mengaplikasikan informasi tersebut secara sistematis ke dalam fungsi manajerial yang diterjemahkan secara nyata dalam kegiatan pengawasan, perencanaan, dan pengawasan (Pitana, 2009). Pengelolaan adalah proses pelaksanaan pencapaian tujuan tertentu yang diselenggarakan dengan pengendalian. Mengelola, pengertiannya lebih dekat ke arah mengendalikan atau menyelenggarakan.

Atraksi wisata dapat di artikan sebagai segala sesuatu yang dapat menarik wisatawan, meliputi benda-benda yang tersedia di alam, hasil ciptaan manusia dan tata cara hidup masyarakat. Selanjutnya sumber daya berbasis alam yang dapat 
dikembangkan menjadi atraksi wisata, menurut Fannel (dalam Pitana, 2009) diantaranya:

1) Letak geografis terkait dengan karakteristik ruang yang menentukan kondisi dan berhubungan dengan beberapa variable lain.

2) Iklim dan cuaca. Ditentukan oleh latitude dan elevation diukur dari permukaan air laut, daratan, pengunungan dan sebagainya.

3) Topografi dan landforms. Bentuk umum dari permukaan bumi (topografi) dan struktur permukaan bumi menjadikan suatu areal geografis memiliki bentang alam yang unik (landform). Aspek tersebut menjadi daya tarik tersendiri yang membedakan kondisi geografis suatu wilayah/benua dengan wilayah/benua lainnya sehinga sangat menarik menjadi atraksi wisata.

4) Surface materials. Berbagai ragam material yang menyusun permukaan bumi, seperti formasi bebatuan alam, pasir, mineral, minyak memiliki keunikan untuk dikembangkan menjadi atraksi wisata.

5) Air. Air memiliki penting dalam menentukan tipe dan level dari rekreasi outdoor, sehingga dikembangkan sebagai wisata pantai/bahari, danau, sungai dan sebagainya.

6) Vegetasi. Vegetasi merujuk pada keseluruhan kehidupan tumbuhan yang menutupi suatu area tertentu. Kegiatan wisata memiliki ketergantungan pada jenis tumbuhan seperti pada kawasan konservasi alam/hutan lindung.

7) Beragam jenis fauna berperan signifikan pada aktivitas wisata misalnya sebagai atraksi wisata berburu atau memancing.

Pengelolaan atraksi wisata yang di maksud dalam penelitian ini adalah usahausaha yang dilakukan oleh masyarakat Desa Wanagiri dengan memanfaatan sempadan Danau Buyan dan Danau Tamblingan dan bentang alam sebagai latar belakang atraksi wisata swafoto.

\section{Metode Penelitian}

Penelitian ini menganalisis implementasi kebijakan dan implikasi pengelolaan atraksi wisata swafoto (selfie) di Desa Wanagiri. Dalam upaya mendalami pengelolaan, penelitian ini juga berusaha menggali implikasi dari kebijakan pengelolaan wisata swafoto, hingga pada akhirnya menemukan hasil apakah 
keberlanjutan dari usaha masyarakat melalui swafoto dapat menjadi rujukan bagi masyarakat lain yang mengembangkan wisata swafoto.

Penelitian kualitatif merupakan bentuk pendekatan yang muncul pada postpositivisme merupakan hasil pergeseran paradigma dengan melihat suatu kenyataan, pembacaan fenomena, atau gejala. Pada pendekatan ini realitas sosial dipandang sebagai suatu yang holistik/menyeluruh, kompleks, dinamis, dan penuh makna. Metode eksplorasi yang di gunakan dalam penelitian kualitatif bertujuan untuk memahami makna dari individu atau kelompok orang yang dianggap berasal dari masalah sosial atau kemanusiaan (Creswell, 2009) melalui pangajuan pertanyaan,analisis data, serta menafsirkan makna.Siapapun yang terlibat dalam penelitian ini harus menerapkan cara pandang yang bergaya induktif terfokus pada makna dan berusaha menerjemahkan kedalam suatu persoalan.

Sumber data primer dalam penelitian ini dilakukan melalui serangkaian wawancara kepada para pengelola wisata swafoto, Bendesa Adat Wanagiri, Kepala Desa Wanagiri, tokoh masyarakat Desa Wanagiri, Kepala Seksi Wilayah I BKSDA Bali, Kepala Dinas Pariwisata Kabupaten Buleleng, serta pihak akademisi. Sumber data sekunder di ambil berdasarkan penelitian kepustakaan (library research), dari berbagai macam sumber yang terkait dengan peran stakeholder dalam pengembangan kawasan pariwisata, termasuk data penunjang yang diambil dari media seperti koran, majalah, dan internet. Selain itu, dilakukan pula tinjauan pada peraturan perundang-undangan dalam hal ini: Undang-Undang Nomor 10 Tahun 2009 tentang Kepariwisataan, Peraturan Menteri Kehutanan RI No. P. 85/MenhutII/2014 tentang Tata Cara Kerja Sama Penyelenggaraan Kawasan Suaka Alam dan Kawasan Pelestarian Alam, Peraturan Pemerintah Nomor 50 Tahun 2011 tentang Rencana Induk Pembangunan Kepariwisataan Nasional tahun 2010-2025, Peraturan Daerah Provinsi Bali Nomor 16 Tahun 2009 Tentang Rencana Tata Ruang Wilayah Provinsi Bali, Rencana Pengelolaan Hutan Jangka Panjang Tahun 2023, Perda RTRW Kabupaten Buleleng No.9 tahun 2013 dan berbagai kesepakatan dalam bentuk MoU antara para pihak dalam pengelolaan atraksi wisata swafoto di Desa Wanagiri. 


\section{Pembahasan}

Proses implementasi merupakan bentuk operasionalisasi atau penyelenggaraan aktivitas yang telah ditetapkan berdasarkan undang-undang dan menjadi kesepakatan bersama antara beragam pemangku kepentingan, aktor, organisasi (public atau privat) dan teknik sinergitas yang digerakkan untuk bekerjasama guna menerapkan kebijakan ke arah tertentu yang dikehendaki (Wahab, 2017). Selanjutnya, dalam operasionalisasi suatu kebijakan sangat ditentukan koordinasi seperti diungkapkan Rimsky Judisseno bahwa koordinasi adalah "roh dan jiwa" yang paling penting dalam sebuah proses implementasi suatu kebijakan (Judisseno, 2017).

Dalam lingkup tataran Desa Pakraman Wanagiri, koordinasi diantara para stakeholder pariwisata terwujud dalam berita acara tertanggal 14 April 2018 sebagai bentuk pelaksanaan butir ke lima kebijakan BKSDA Bali tentang penunjukan pengelolaan atraksi wisata swafoto di masing-masing banjar pakraman. Berdasarkan berita acara yang ditandatangani oleh Bendesa Desa Pakraman, Prajuru Desa Pakraman Wanagiri beserta para pengelola atraksi wisata swafoto maka ditetapkan: (1) Pucak Selfie dikelola oleh Banjar Pekraman Yeh Ketipat, (2) Selfie Menara Bambu Hitam dikelola oleh Banjar Pekrama Bhuanasari. (3) Selfie Hidden Hill dikelola Banjar Pekraman Asah Panji Kelod, (4) Selfie Danu Kembar dikelola oleh Banjar Pekraman Asah Panji Kaja.

Penunjukan diberikannya masing-masing banjar pakraman mengelola hanya satu atraksi swafoto adalah upaya membatasi penggunanan lahan kawasan konservasi untuk kegiatan pariwisata. Untuk mengindari terjadinya persaingan yang tidak sehat diantara para pengelola atraksi di masing-masing banjar adat menyangkut harga tiket kunjungan, maka disepakati tiket masuk wisatawan local Rp.20.000,- (dua puluh ribu rupiah) di luar Pendapatan Negara Bukan Pajak (PNBP) 
sebesarRp.5.000,-(lima ribu rupiah). Untuk wisatawan asing/mancanegara Rp. 45.000,- (empat puluh ribu rupiah) diluar PNBP sebesar Rp. 100.000,- (seratus ribu rupiah) untuk sekali kunjungan.

Dalam kesepakatan tersebut juga ditentukan retribusi ke Desa Pekraman Wanagiri disesuaikan dengan kondisi tingkat kunjungan serta usia berjalannya pengelolaan atraksi. Untuk Puncak Selfie yang dinilai tingkat kunjungan wisatawannya selalu ramai memberikan retribusi ke Desa Pekraman sebesar Rp. 50.000,- (lima puluh ribu rupiah) juga wajib menyetor Rp. 50.000,- (lima puluh ribu) juga ke Banjar Pekraman Yeh Ketipat ditambah setoran parkir sebesar Rp. 30.000,(tiga puluh ribu rupiah) per hari.

Sementara itu Selfie Menara Bambu Hitam hanya dikenakan retribusi sebesar 20\% dari pendapatan bersih dalam 1 bulan di tambah 10\% yang diperoleh dari pendapatan parkir kepada Banjar Pekraman Bhuanasari. Sebagai pionir dalam pengelolaan atraksi wisata swafoto di Desa Wanagiri, Selfie Wanagiri Hidden Hill berkewajiban memberikan retribusi sebesar Rp. 50.000,- (lima puluh ribu rupiah) kepada Desa Pekraman dan Banjar Pekraman Asah Panji Kelod, ditambah 10\% diberikan ke Banjar Asah Panji Kaja serta retribusi yang di peroleh dari pendapatan parkir sebesar Rp. 20.000,- (dua puluh ribu rupiah) tiap bulannya.Khusus untuk anggota pengelola Selfie Pucak Banyumala karena lokasi atraksi wisatanya tidak dalam zona pemanfaatan dan ketika kesepakatan ini dilakukan telah di bongkar, maka anggota pengelolanya akan di masukan ke pengelola atraksi swafoto Wanagiri Hidden Hill dan Danau Kembar. Agar tiap-tiap kelompok mendapat jumlah pengelola yang sama, maka ditentukan dengan cara diundi.

Dalam proses berjalannya implementasi kebijakan pengelolaan atraksi swafoto di lahan kawasan konservasi terlihat mulai kondusif. Masing-masing pengelola melaksanakan ketentuan yang telah ditetapkan, salah satunya dengan penyeragaman tiket obyek masuk atraksi wisata swafoto sesuai ketentuan yang berlaku. Terdapat perbedaan jumlah kunjungan wisatawan rata-rata perhari di masing-masing pengelola atraksi. Selain keunikan dan kreativitas yang ditawarkan 
oleh masing-masing pengelola, kondisi alam yang sering berkabut serta akses masuk menuju lokasi sangat mempengaruhi tingkat kunjungan. Wisatawan yang datang berkunjung ke Desa Wanagiri didominasi oleh wisatawan domestik baik datang sebagai group diantar oleh agen perjalanan wisata maupun sebagai Free Individual Traveler (FIT).

Tabel 1. Asumsi Pendapatan Tiket Atraksi Wisata Swafoto

\begin{tabular}{|c|c|c|c|c|c|c|}
\hline $\begin{array}{c}\text { Nama } \\
\text { Atraksi } \\
\text { Swafoto }\end{array}$ & $\begin{array}{c}\text { Estimasi } \\
\text { Wisatawan } \\
\text { Asing }\end{array}$ & $\begin{array}{c}\text { Estimasi } \\
\text { Wisatawan } \\
\text { Domestik }\end{array}$ & $\begin{array}{c}\text { Harga } \\
\text { Tiket } \\
\text { Wisman }\end{array}$ & $\begin{array}{c}\text { Harga Tiket } \\
\text { Wis. } \\
\text { Domestik }\end{array}$ & $\begin{array}{c}\text { Estimasi } \\
\text { Pendapatan } \\
\text { Per Hari }\end{array}$ & $\begin{array}{c}\text { Estimasi } \\
\text { Pendapatan } \\
\text { Per Bulan }\end{array}$ \\
\hline $\begin{array}{c}\text { Wanagiri } \\
\text { Hidden Hill }\end{array}$ & $\begin{array}{c}50 \% \\
(40 \text { orang) }\end{array}$ & $\begin{array}{c}50 \% \\
(40 \text { orang })\end{array}$ & 45.000 & 20.000 & 2.600 .000 & 78.000 .000 \\
\hline $\begin{array}{c}\text { Pucak Selfie } \\
(80 \text { orang })\end{array}$ & $\begin{array}{c}43 \% \\
(60 \text { orang })\end{array}$ & 45.000 & 20.000 & 4.800 .000 & 144.000 .000 \\
\hline $\begin{array}{c}\text { Menara } \\
\text { Bambu }\end{array}$ & $\begin{array}{c}39 \% \\
(17 \text { Orang })\end{array}$ & $\begin{array}{c}67 \% \\
(27 \text { Orang })\end{array}$ & 45.000 & 20.000 & 1.220 .000 & 36.600 .000 \\
\hline $\begin{array}{c}\text { Danau } \\
\text { Kembar }\end{array}$ & $\begin{array}{c}50 \% \\
(15 \text { orang })\end{array}$ & $(15$ orang $)$ & 45.000 & 20.000 & 975.000 & 28.500 .000 \\
\hline
\end{tabular}

(Sumber: Olahan Peneliti)

Berdasarkan matriks estimasi pendapatan dari pengelolaan atraksi wisata swafoto, maka secara ekonomi tingginya pendapatan pengelola masing-masing atraksi swafoto. Sesuai berita acara yang telah disepakati,jumlah pendapatan akan dibagi sesuai prosentase kepada Desa Adat Wanagiri dan di distibusikan kembali pada warganya.

Tabel 2.Asumsi Pendapatan Parkir Atraksi Wisata Swafoto

\begin{tabular}{|c|c|c|c|c|}
\hline $\begin{array}{c}\text { Nama } \\
\text { Atraksi } \\
\text { Swafoto }\end{array}$ & $\begin{array}{c}\text { Estimasi } \\
\text { Mobil }\end{array}$ & $\begin{array}{c}\text { Harga Parkir } \\
\text { Mobil }\end{array}$ & $\begin{array}{c}\text { Estimasi } \\
\text { Pendapatan } \\
\text { Per Hari }\end{array}$ & $\begin{array}{c}\text { Estimasi } \\
\text { Pendapatan } \\
\text { Per Bulan }\end{array}$ \\
\hline $\begin{array}{c}\text { Wanagiri } \\
\text { Hidden Hill }\end{array}$ & 16 & 5.000 & 80.000 & 2.400 .000 \\
\hline Pucak Selfie & 28 & 5.000 & 140.000 & 4.200 .000 \\
\hline $\begin{array}{c}\text { Menara } \\
\text { Bambu Hitam }\end{array}$ & 9 & 5.000 & 45.000 & 1.350 .000 \\
\hline $\begin{array}{c}\text { Danau } \\
\text { Kembar }\end{array}$ & 6 & 5.000 & 30.000 & 900.000 \\
\hline
\end{tabular}

(Sumber: Olahan Peneliti) 
Kecenderungan masyarakat melihat motif ekonomi diwujudkan membangun wahana swafoto dilengkapi ayunan masih berlanjut ke lahan-lahan pribadi maupun hutan di sekitar desa. Tanpa biaya yang tinggi dan penggunaan lahan pribadi, masyarakat berorientasi meraih keuntungan secara cepat dengan memanfaatkan trend wisatawan berswafoto, menyebabkan masyarakat secara massif terus membangun wahana swafoto. Hingga saat penelitian ini berlangsung, tercatat 14 titik yang telah terbangun dengan berbagai konsep atraksi swafoto di seluruh wilayah Desa Wanagiri. Namun penelitian ini hanya memfokuskan pada atraksi wisata swafoto yang kelola oleh empat Banjar Adat di Desa Wanagiri di sepanjang pinggiran sebagai bagian dari Taman Wisata Alam Danau Buyan dan Tamblingan.

Dengan banyaknya titik lokasi atraksi swafoto, dari sudut pandang wisatawan akan lebih banyak pilihan untuk mengekspresikan pengalaman dirinya di media sosial. Tapi bagi para pengelola atraksi, peniruan konsep atraksi swafoto kerap menimbulkan persaingan yang tidak sehat dan mengurangi tingkat kunjungan. Implikasi lain yang terjadi adalah menurunnya pembagian pendapatan pada masing-masing anggota kelompok atraksi swafoto. Melihat kondisi tersebut, pengelola atraksi Wanagiri Hidden Hill memohon kepada kelihan Desa Pekraman Wanagiri untuk membuat awig-awig yang mengatur agar masing-masing pengelola atraksi tidak meniru konsep yang telah diciptakan oleh kelompok sebelumnya. Inti dari tuntutan salah satu kelompok pengelola atraksi bertujuan agar ke empat atraksi wisata swafoto memiliki keunggulan dan keunikan sendiri dan bersaing secara sehat dalam menarik kunjungan wisatawan.

Atraksi wisata swafoto di Desa Wanagiri merupakan atraksi baru yang perlu di dukung dengan pengaturan kebijakan lebih lanjut untuk keberlanjutan usahanya. Sebagai bagian industri kepariwisataan yang melibatkan host dan guest, atraksi wisata swafoto dalam proses pengelolaannya menimbulkan pola-pola relasi di antara stakeholder pariwisata. Sepanjang proses berjalannya pengelolaan atraksi wisata swafoto di Desa Wanagiri, tidak bisa dilepaskan dari peran aktor yang 
terlibat dalam kesuluruhan proses interaksi yang terjadi. Terdapat sejumlah aktor yang berperan dan saling mempengaruhi proses pengelolaan atraksi wisata. Berdasarkan basis pola menetap dan kepentingan yang dimiliki para aktor, terlihat dalam matrik tipologi aktor.

Tabel 3. Tipologi Aktor

\begin{tabular}{|c|c|c|}
\hline \multicolumn{3}{|c|}{ Tipologi Aktor } \\
\hline Pelaku/Aktor & Akses & Pola Menetap dan Kepentingan \\
\hline Pemerintah (BKSDA) & Utama & Internal \\
\hline Masyarakat Lokal & Utama & Kuasi Internal \\
\hline Pemerintah Dispar & Umum & Kuasi Internal \\
\hline Investor & Umum & Kuasi Internal \\
\hline
\end{tabular}

(Diadopsi dari Sunarta dkk, 2017)

Berdasarkan pola menetap dan kepentingan yang dimiliki, pihak pemerintah pusat dalam hal ini BKSDA Bali memiliki akses utama dan disebut sebagai aktor internal. Sesuai dengan kewenangan yang dimilikinya, BKSDA memiliki kepentingan dalam mengatur tata kelola pemanfaatan kawasan TWA. Walaupun secara "de facto" dan "de yure", masyarakat Desa Wanagiri memiliki akses utama dalam pariwisata, namun keterlibatan dalam bidang pariwisata baru dimulai melalui pengelolaan atraksi swafoto. Posisi demikian menempatkan masyarakat sebagai kuasi internal. Terlibatnya masyarakat di sektor pariwisata direpresentasikan oleh perangkat Desa Adat melalui kerjasama pihak BKSDA Bali, serta difasilitasi oleh Dinas Pariwisata Kabupaten Buleleng.

Sebagai bagian dari sebuah proses perkembangan industri pariwisata di Indonesia, pengelolaan atraksi wisata swafoto di Desa Wanagiri memberikan pengaruh pada tata kehidupan sosial masyarakatnya. Beberapa rangkaian konflik yang muncul ke permukaan dalam proses pengelolan atraksi bersumber pada perbedaan pandangan para aktor terhadap pemanfaatan sumber daya alam yang dimiliki. Berbagai konflik tersebut dipandang oleh masyarakat sebagai hal yang 
merugikan. Kesadaran tentang konflik dilakukan dengan membentuk pola-pola relasi di antara stakeholder pariwisata dengan menerima kebijakan yang telah disepakati demi tujuan bersama kearah tatanan sosial yang inklusif. Inklusifitas sosial terjadi ketika masyarakat memaknai perbedaan sebagai sesuatu yang bersifat universal sehingga memotivasi untuk mencapai tujuan bersama.

Atraksi swafoto di Desa Wanagiri telah membuka peluang lapangan pekerjaan bagi masyarakat. Pernyataan tersebut seperti diungkapkan Bendesa Adat Desa Wanagiri,Dewa Made Merta :

...dulu masyarakat saya sangat sulit mendapatkan pekerjaan yang layak, akhirnya pemuda pemudi disini merantau ke Denpasar bahkan ada yang ikut kapal pesiar. Sejak adanya atraksi selfie,banyak yang kembali ke desa, hampir 300 orang sekarang terserap di atraksi wisata swafoto yang ada di desa ini,baik yang ada dalam kawasan konservasi maupun yang dikelola di hutan desa atau menjadi pemandu treeking. pernah pada musim tertentu saat tanaman kopi tidak maksimal, terpaksa kami hanya menonton danau.(Wawancara, 25 Juni 2018)

Selain itu terjadinya diversifikasi lapangan pekerjaan, dimana masyarakat yang awalnya bekerja di sektor perkebunan dan pertanian,berdagang. Saat ini mulai mengarah pada sektor kerajinan dengan membuat berbagai model wahana swafoto yang sangat di minati oleh pengelola atraksi swafoto di Bali maupu di luar Bali.

Melalui pola relasi diantara para aktor, masyarakat mendapat pembinaan tentang konservasi sumber daya alam melalui ceramah-ceramah, maupun sebagai hasil interaksinya dengan wisatawan. Secara perlahan kesan kumuh bahkan stigma sebagai tempat membuang sampah bagi masyarakat kini berubah wajah desa menjadi destinasi wisata swafoto favorit bagi wisatawan domestik bahkan wisatawan mancanegara berdasarkan konsep pariwisata berkelanjutan. 


\section{Simpulan dan Saran}

Simpulan yang didapat adalah bahwa atraksi swafoto di Desa Wanagiri memberikan pengaruh terhadap pola relasi sinergitas yang terjadi di antara para stakeholder pariwisata baik pusat, daerah maupun menyentuh pola kehidupan masyarakat. Hal tersebut terwujud pada aspek ekonomi dan lingkungan masyarakat. Tumpang tindih kebijakan antara instansi pemerintah pusat dan pemerintah daerah, dapat disikapi dengan dengan diskresi oleh pejabat di daerah sebagai intreprestasi pemerintah pusat yang paling memiliki wewenang langsung terhadap sumber daya pariwisata. Diskresi tersebut memandang aspek sosiologis masyarakat sebagai pengelola atraksi wisata swafoto menjadi prioritas untuk menghindarkan terjadinya konflik horizontal. Secara filosofis atraksi wisata swafoto merupakan atraksi yang dilakukan wisatawan dengan memotret diri sendiri kemudian di unggah ke media sosial sebagai bentuk ekistensi diri sehingga menjadi trend berwisata saat ini. Hal ini dapat dimaknai oleh masyarakat Desa Wanagiri bahwa, momentum pengelolaan atraksi wisata ini merupakan media bagi masyarakat untuk bercermin tentang makna kebersamaan, seiring sejalan dalam suka dan duka melalui pola relasi antar aktor yang terjadi selama ini dalam ruang hidup bersama di Desa Wanagiri atau yang sering disebut sebagai konsep Sagilik Saguluk Salunglung Sabayantaka.

Saran bagi Pemerintah Daerah Provinsi Bali, secara khusus untuk mengindarkan terjadinya tumpang tindih kewenangan yang terjadi pada pengelolaan atraksi wisata yang berada dalam kawasan konservasi dan disparitas ekonomi,lingkungan dan sosial budaya antar kabupaten/kota pada umumnya, maka kebijakan sektor pariwisata di Provinsi Bali seharusnya menjadi wewenang pemerintah provinsi bukan kewenangan pemerintah kabupaten/kota. Berdasarkan Pasal 11 Undang-Undang Otonomi daerah, mengenai urusan pemerintah konkuren,maka pemerintah provinsi memiliki urusan pemerintahan wajib dan urusan pemerintahan pilihan. Dalam pasal 12 ayat 3 secara tegas menyatakan sektor 
pariwisata merupakan urusan pemerintah pilihan. Terwujudnya pembagian urusan pemerintahan konkuren antara Pemerintah Pusat dan Daerah provinsi akan dapat terlaksana dengan baik apabila dilakukan dengan prinsip akuntabilitas, efisiensi, dan eksternalitas, untuk terwujudnya kepentingan strategis nasional.

Untuk pengelola atraksi wisata hendaknya lebih memperhatikan ketentuan kebijakan yang telah ditetapkan. Perhatian yang serius kepada wisatawan yang melakukan swafoto guna menghindari kejadian-kejadian yang tidak diinginkan. Karena jika terjadi musibah terhadap wisatawan saat melakukan swafoto, maka akan cepat tersebar di media sosial. Kondisi tersebut tentunya akan berpengaruh pada kredibilitas pengelola atraksi wisata dan citra pariwisata nasional. Atraksi wisata swafoto merupakan destinasi baru yang belum pernah diatur dalam kebijakan kepariwisataan di Indonesia. Dalam perumusan kebijakan selanjutnya maka sangat dibutuhkan pengkajian lebih lanjut terhadap definisi konsep swafoto agar tidak menimbulkan kesalahan dalam penentuan arah kebijakan berikutnya.

\section{Daftar Pustaka}

Antariksa, B., 2016. Kebijakan Pembangunan Kepariwisataan. 1 Hrsg. Malang: Intrans Publishing.

Creswell, J. W., 2009. Research Design : Qualitative, Quantitative, and Mix Methodes Approaches. 1 Hrsg. New Burry Park: Sage Publication.

Foucault, M., 1975. Discipline and Punish: Birth of the Prison. New York: Random House.

Hamzah, Y. I., 2013. Potensi Media Sosial Sebagai Sarana Promosi Interaktif Bagi Pariwisata Indonesia. Jurnal Kepariwisataaan Indonesia, 8(3), pp. 1-9.

Judisseno, R. K., 2017. Aktivitas dan Kompleksitas Kepariwisataan. 1 Hrsg. Jakarta: PT.Gramedia.

Kusrini, 2013. Selfie sebagai Perangkat Citra Diri Masyarakat Urban. Journal of Urban Society's Arts, 13(1), pp. 34-36.

Listiono, 2017. Instagram, Wisata Foto dan Dampaknya Terhadap Peningkatan Jumlah Wisatawan di Yogyakarta. Yogyakarta, URECOL. 
Pearce, J., 2015. Social Representations of Tourist Selfies: New Challenges for Sustainable Tourism. Builiding Exelent in Sustainable Tourism Education Network, p. 59.

Pearce, J. \& Moscardo, G., 2015. Social Representations of Tourist Selfies: New Challenges for Sustainable Tourism. Pretoria, BEST EN, pp. 59-73.

Pitana, D., 2009. Pengantar Ilmu Pariwisata. I Hrsg. Yogyakarta: Andi Yogyakarta.

Pitanatri, D. S. \& Putra, D. N., 2016. Wisata Kuliner Atribut Baru Destinasi Ubud. 1 Hrsg. Denpasar: Jagat Press.

Putra, I. B. W., 2016. Teori Hukum Dan Orientasi Kebijakan. 1 Hrsg. Denpasar: Udayana Univeristy Press.

Sunarta, I. N. et al., 2017. Typology of Tri Ning Danu Tourist in Bedugul Bali. IRCS, 1 Februari, Band 1, pp. 88-91.

Urry, J. \& Larsen, J., 2011. The Tourist Gaze 3.0. 3 Hrsg. London: SAGE Publication.

Wahab, S. A., 2017. Analisis Kebijakan dari formulasi ke Penyusunan model-model implementasi kebijakan Publik. 6 Hrsg. Jakarta: Bumi Aksara.

\section{Profil Penulis}

I Gede Ngurah Wirayuda Arsana adalah alumnus Program Studi Magister Pariwisata Universitas Udayana tahun 2018 dan Sarjana Jurusan Hukum Sekolah Tinggi Hukum Bandung tahun 1998. Minat penelitian Wirayuda adalah tentang community based tourism dan sociology in tourism.

I Nyoman Sunarta adalah Dosen Magister Pariwisata Universitas Udayana, dan kini menjabat sebagai Dekan Fakultas Pariwisata Universitas Udayana. Minat penelitian Sunarta adalah ecotourism dan hidrology.

I Nyoman Sukma Arida adalah Dosen Magister Pariwisata Universitas Udayana, dan kini menjabat sebagai Wakil Dekan III Bidang Kemahasiswaan Fakultas Pariwisata Universitas Udayana. Minat penelitian Sukma adalah community based tourism dan ecotourism. 